Teka Kom. Hist. OL PAN-TN KUL, 2020, 2(17), 61-78

DOI: http://dx.doi.org/10.18290/teka.20.4

\title{
MARYNARZE W WALCE O GRANICE I NIEPODLEGŁOŚĆ POLSKI W LATACH 1918-1920
}

\author{
Dariusz Nawrot \\ Wyższa Szkoła Administracji i Biznesu \\ im. E. Kwiatkowskiego w Gdyni \\ Katedra Administracji \\ University of Business and Administration \\ of E. Kwiatkowski in Gdynia \\ Department of Administration \\ e-mail: dnawrot11@wp.pl
}

Streszczenie. Miejsce i rola Polskiej Marynarki Wojennej w walce o granice i niepodległość w latach 1918-1920 to temat, który nie znalazł dotąd godnego miejsca w piśmiennictwie naukowym. Pomimo iż ukazało się wiele opracowań na temat narodzin Drugiej Rzeczypospolitej, to tylko nieznaczny ich procent traktuje o roli Polskiej Marynarki Wojennej w tym obszarze.

Tymczasem - moim zdaniem - nawet pobieżna analiza dokonań marynarzy w tym obszarze upoważnia nas do stwierdzenia, iż była ona znacząca zarówno w czasie pokoju, jak i w czasie wojny. Szczególnym tego wyrazem była rola Polskiej Marynarki Wojennej w rewindykacji Pomorza i udział marynarzy w wojnie polsko-rosyjskiej. Trzeba dodać, że marynarze w wojnie polsko-rosyjskiej walczyli nie tylko na wodzie (Flotylle Rzeczne: Pińska i Wiślana), ale także na lądzie w roli piechoty. Do tego bezprecedensowego w historii wojskowości zdarzenia, jakim było powołanie rozkazem Ministra Spraw Wojskowych Pułku Morskiego, doszło na wniosek ówczesnego dowódcy Polskiej Marynarki Wojennej, kontradmirała Kazimierza Porębskiego.

Tym intrygującym zagadnieniom związanym z genezą, rozwojem i działalnością Polskiej Marynarki Wojennej w okresie budowy zrębów II Rzeczypospolitej poświęcony jest niniejszy artykuł, opracowany na podstawie najnowszych przedmiotowych badań.

Słowa kluczowe: Polska Marynarka Wojenna; rewindykacja Pomorza; Pułk Morski; komandor Bogumił Nowotny; kontradmirał Kazimierz Porębski.

11 listopada 1918 r., gdy Niemcy zmuszone zostały do podpisania aktu kapitulacji, rozpoczęło się przejmowanie władzy na ziemiach pozostających dotąd pod ich okupacją. Jako pierwsze spod dominacji niemieckiej uwolnione zostały ziemie północnej 
części Królestwa Polskiego ${ }^{1}$ z dwoma dużymi miastami - Warszawą i Łodzią. Tam też po powrocie Józefa Piłsudskiego z więzienia w Magdeburgu, ukonstytuował się rząd, któremu podporządkowały się wszystkie ośrodki władzy tworzone na ziemiach byłych zaborów: rosyjskiego i austriackiego.

Odzyskanie wolności nie oznaczało jednak końca problemów dla polityków i działaczy niepodległościowych. Po 123 latach niewoli wszystko trzeba było zaczynać praktycznie od zera. Jednym z najważniejszych problemów było ustalenie granic państwowych. Na tym tle ścierały się dwie koncepcje: federacyjna i inkorporacyjna. Pierwsza, zgodnie z poglądami Naczelnika Państwa Józefa Piłsudskiego, postulowała utworzenie federacji niepodległych państw wschodnioeuropejskich, obejmującej Polskę, Ukrainę, Białoruś i kraje bałtyckie. Druga zgodnie z poglądami przywódcy Narodowej Demokracji Romana Dmowskiego zakładała wcielenie do Polski ziem wschodnich z Wilnem i Lwowem oraz późniejszą polonizację zamieszkujących je Ukraińców, Białorusinów i Litwinów².

Pomimo tych niewątpliwie istotnych różnic, zwolennicy obydwu koncepcji w jednym byli zgodni - Polska powinna powrócić nad Bałtyk. Opierając się na punkcie 13. deklaracji prezydenta USA Woodrowa Wilsona, domagali się przyłączenia do Polski całego wybrzeża pomorskiego wraz z Gdańskiem. Dostęp Polski do morza traktowany był przez wszystkich jako podstawowy warunek jej niezależnego bytu i rozwoju. $\mathrm{Z}$ myślą o tym podejmowane były różnorodne działania na długo jeszcze przed formalnym odzyskaniem niepodległości. Szczególnym tego wyrazem było utworzenie zalążka polskiej marynarki wojennej pod patronatem generała Tadeusza Rozwadowskiego, doradcy Rady Regencyjnej Królestwa Polskiego. Taki zalążek tworzony był z ochotników, którzy swą morską specjalność zdobyli w służbie pod banderami państw zaborczych. Według szacunkowych danych w latach I wojny światowej we flotach państw zaborczych służyło co najmniej kilkadziesiąt tysięcy Polaków, w tym około 200 oficerów3 . Wielu z nich już wczesną jesienią $1918 \mathrm{r}$. powracało $\mathrm{w}$ rodzinne strony $\mathrm{z}$ nadzieją, iż nadchodzi długo oczekiwana niepodległość. Jednym z pierwszych był Bogumił Nowotny, były Fregattenkapitän (komandor porucznik) Cesarsko-Królewskiej Marynarki Wojennej Austro-Węgier.

\footnotetext{
1 Królestwo Polskie (niem. Königreich Polen) - fragmentaryczna państwowość, wyrażająca się w istnieniu instytucji państwowych pod egidą Rady Regencyjnej, wyposażonej formalnie przez mocarstwa okupujące terytorium Królestwa Polskiego w atrybuty zwierzchnictwa. Szerzej: W. KoMarnicki, Polskie prawo polityczne, Wydawnictwo Sejmowe, Warszawa 2008, s. 41-54.

2 Szerzej: J. BARDACH, B. LeŚNOdorski, M. PietrZaK, Historia ustroju i prawa polskiego, Warszawa 2009; S. Roszak, J. KŁaczkow, Poznać przeszłość. Wiek XX, Warszawa 2015.

3 D. Nawrot, Korpus oficerski Marynarki Wojennej II Rzeczypospolitej, Warszawa 2005, s.15.
} 
Bogumił Nowotny to jeden z najbardziej znanych oficerów Cesarsko-Królewskiej Marynarki Wojennej okresu I wojny światowej. Duży rozgłos przyniósł mu udział w wielkiej operacji austro-węgierskiej marynarki wojennej na Adriatyku, 24 maja 1915 r. Zadaniem ówczesnego Korvettenkapitäna (komandora podporucznika) Bogumiła Nowotnego, dowódcy niszczyciela „Scharfchütze”, było zniszczenie włoskiej bazy morskiej w Porto Corsini. Było to niezwykle trudne zadanie z uwagi na lokalizację bazy w głębi lądu, przeszło $1200 \mathrm{~m}$ od linii brzegowej. Wiodący do niej kanał miał zaledwie $30 \mathrm{~m}$ szerokości, co znacznie ograniczało możliwości manewrowe tak dużego okrętu, jakim był „Scharfchütze” (dł. 68,1 m, szer. 6,3 m). Uwzględniając te uwarunkowania, Nowotny zdecydował o wprowadzeniu okrętu do kanału rufą naprzód. O tym, jak ryzykowny był to manewr, pokazały już pierwsze minuty jego realizacji. Wolno płynący okręt stanowił doskonały cel dla włoskich żołnierzy rozmieszczonych w okopach ciągnących się wzdłuż obu brzegów kanału. Pomimo rosnącego z każdą minutą zagrożenia, Nowotny utrzymując „całą wstecz” doprowadził okręt do celu. Zbombardowany port opuścił tą samą drogą, którą do niego dotarł, z tą tylko różnicą, iż tym razem okręt płynął dziobem do przodu. Brawurowa akcja załogi „Scharfchütze” została rozsławiona przez austriacką propagandę wojenną - specjalną akwarelową pocztówkę namalował znany niemiecki marynista Willy Stower".

W toku dalszej wojny Bogumił Nowotny sprawdził się także jako komendant twierdzy na wyspie Lussinnpiccolo (obecnie Otok Losin). W kwietniu 1918 r., z upoważnienia wiedeńskiej admiralicji, objął obowiązki specjalisty do spraw żeglugowych przy Radzie Regencyjnej Królestwa Polskiego. We wrześniu tegoż roku wobec rozpadu monarchii habsburskiej z upoważnienia wspomnianego generała Tadeusza Rozwadowskiego przystąpił do organizowania powracających do kraju marynarzy.

Na przełomie października i listopada pod komendą Bogumiła Nowotnego było już około 600 marynarzy ${ }^{5}$. To dzięki nim możliwe było przejęcie i zabezpieczenie 11 listopada 1918 r. 25 statków, 100 barek oraz 20 motorówek Weichsel-Flotille i Schiffahrtsgruppe, cumujących w Warszawie i Modlinie. Dzień później, realizując umowę zawartą z komisarzem niemieckiej flotylli, przetransportowali ponad 300 uchodźców (marynarzy i żołnierzy garnizonu warszawskiego z dowódcą generałem-gubernatorem Hansem von Beselerem) z Warszawy do Torunia. Na wykorzystanym

${ }^{4}$ Szerzej: D. Nawrot, Akcja w Kanale Porto Corsini i bitwa w Cieśninie Otranto, czyli rzecz o bojowych dokonaniach Bogumiła Nowotnego pod czerwono-biato-czerwona bandera, „Colloquium” Wydział Nauk Humanistycznych i Społecznych Akademii Marynarki Wojennej, 2011, nr 4, s. 55-74.

5 B. Nowotny, Wspomnienia, Gdynia 2006, s. 170. 
do tego celu statku „Ulderup” (późniejszy „Lokietek”), po raz pierwszy od czasu powstania styczniowego, podniesiona została biało-czerwona bandera ${ }^{6}$.

Niewątpliwie to dzięki tym marynarzom skupionym wokół osoby Bogumiła Nowotnego idea budowy Polskiej Marynarki Wojennej (PMW) mogła wejść w etap realizacji już w kilkanaście dni po ukonstytuowaniu tymczasowych organów władzy odrodzonej Polski. Formalnie do powstania Polskiej Marynarki Wojennej doszło na podstawie dekretu Naczelnika Państwa Józefa Piłsudskiego (nr 155) z 28 listopada 1918 r. $^{7}$ Na mocy tego dokumentu, zrządzeniem losu wydanego w 291. rocznicę bitwy pod Oliwą, pierwszym dowódcą Polskiej Marynarki Wojennej, czyli szefem Sekcji Marynarki przy Ministerstwie Spraw Wojskowych został mianowany pułkownik marynarki Bogumił Nowotny (do 1922 r. marynarze nosili stopnie używane w wojskach lądowych z dodatkiem marynarki) ${ }^{8}$.

Wydanie dekretu przez Naczelnika Państwa Józefa Piłsudskiego o powołaniu do życia Polskiej Marynarki Wojennej w sytuacji, gdy Pomorze znajdowało się jeszcze pod okupacją niemiecką, było aktem o dużym znaczeniu politycznym. W języku polityki było to jednoznaczne oświadczenie wobec całego świata, a w tym wobec uczestników konferencji pokojowej w Paryżu, że dla Polski sprawa dostępu do morza jest kwestią poza wszelką dyskusją. W ślad za dekretem Naczelnika Państwa ukazał się rozkaz Ministra Spraw Wojskowych, na mocy którego do dyspozycji marynarzy oddane zostały koszary i port rzeczny w Modlinie. Tam niezwłocznie przystąpiono do tworzenia pierwszych oddziałów Marynarki Wojennej: Flotylli Wiślanej i Batalionu Morskiego. Flotylla zgodnie z założeniami tworzona była z myślą o ochronie wojskowych transportów wodnych na Wiśle, natomiast Batalion Morski przewidziany był do przejęcia i ochrony polskiego Wybrzeża.

Równolegle do działań dotyczących budowy marynarki wojennej prowadzone były prace związane z tworzeniem zrębów polskiej gospodarki morskiej. Prace te nabrały charakteru zorganizowanej działalności już 1 października 1918 r. W tym dniu z inicjatywy Kazimierza Porębskiego, byłego rosyjskiego kontradmirała, doszło do utworzenia Stowarzyszenia Pracowników na Polu Rozwoju Żeglugi „Bandera Polska". Stowarzyszenie to, pierwsza w historii Polski organizacja społeczna o profilu morskim, odegrało bardzo ważną rolę w nakreśleniu koncepcji przyszłej polityki morskiej?.

6 J.W. Dyskant, Lądowa droga Batalionu Morskiego do morza polskiego, w: Błogosławiony Ks. Kmdr ppor. Władysław Miegoń. Materiały z sesji towarzyszacej obchodom 80 rocznicy Zaślubin Polski z Morzem, red. D. Duda [i in.], Puck 2000, s. 44.

7 S.M. Piaskowski, Kroniki Polskiej Marynarki Wojennej 1918-1946, t. I, Albany, NY 1983, s. 22.

8 D. Nawrot, Zakon dżentelmenów morskich II Rzeczypospolitej, Gdynia 2018, s. 27.

9 Z. MACHALIŃSKI, Michat Borowski, „Nautologia”, 1986, nr 4, s. 22. 
Należy dodać, iż Kazimierz Porębski, pierwszy prezes Stowarzyszenia „Bandera Polska”, był nie tylko wielkim znawcą spraw morskich o szerokich horyzontach intelektualnych, ale także człowiekiem nieprzeciętnie odważnym. Swojej wyjątkowości dowiódł już jako młody oficer w wojnie rosyjsko-japońskiej w bitwie na Morzu Żółtym, 28 czerwca 1904 r. Wówczas to ówczesny lejtnant K. Porębski, zastępca dowódcy na krążowniku „Nowik”, odmówił wykonania rozkazu swego przełożonego nakazującego mu zawrócenie okrętu do bezpiecznej bazy w Port Artur. W konsekwencji „Nowik”, jako jedyny okręt z bazy w Port Artur nie wpadł w ręce wroga. Wyczyn ten rozsławiając nazwisko Porębskiego, przyniósł mu jednak również realne zagrożenie. Zgodnie z rosyjskim regulaminem sprawcę tak ciężkiego wykroczenia, jakim była odmowa wykonania rozkazu na polu walki, czekał sąd, który zwykle orzekał karę śmierci przez rozstrzelanie. Od tego rodzaju konsekwencji niesubordynowanego oficera uchroniła interwencja cara. Car nie tylko nie dopuścił do ukarania lejtnanta Porębskiego, ale wręcz przeciwnie - wyróżnił go za ten bezprecedensowy akt niesubordynacji „Złotą szablą” z wygrawerowanym napisem „Za odwagę" oraz Orderem św. Jerzego ${ }^{10}$.

Podczas I wojny światowej Kazimierz Porębski, już jako kontradmirał, dowodził brygadą krążowników Floty Czarnomorskiej ${ }^{11}$. Ostatnim jego stanowiskiem w rosyjskiej flocie była funkcja szefa Wydziału Sztabu Frontu Północno-Zachodniego. Z tego stanowiska podał się do dymisji 19 sierpnia 1917 r. ${ }^{12}$ Niewątpliwie przyczyn dymisji Porębskiego upatrywać należy w jego silnie rozwiniętej świadomości narodowej oraz w rozwijającej się pod wpływem wydarzeń na froncie nadziei na bliskie odrodzenie Polski.

Flotę rosyjską po 27 latach służby opuszczał z opinią wybitnego specjalisty i doskonałego morskiego dowódcy. O wszechstronnych zainteresowaniach i szerokich horyzontach intelektualnych admirała świadczy m.in. jego udokumentowana działalność w dziedzinie techniki i budownictwa okrętowego, w organizacji flotylli rzecznych, w administracji i zarządzaniu flotą handlową, w kierowaniu pracami hydrograficznymi a także w organizacji szkolnictwa morskiego ${ }^{13}$.

${ }^{10}$ Por. K. Borchardt, Znaczy równik na rumbie, Gdańsk 1992, s. 20-22; C. Ciesielski, Twórcy Polskiej Marynarki Wojennej. Uznanie i represje (1918-1946; 1945-1951), Gdańsk 1995, s. 10-11.

${ }^{11}$ C. Ciesielski, Twórcy Polskiej Marynarki Wojennej, s. 11; J. PerteK, Kazimierz Porębski (18721933), w: Polski Stownik Biograficzny, t. XXVII/4, Warszawa 1983, s. 656; J. CzerwiŃski, Wiceadmirat Kazimierz Porębski, „Nasze Sygnały” [Londyn], 1988, nr 162, s. 33-34.

${ }^{12}$ Centralne Archiwum Wojskowe [dalej: CAW], Teczka Akt Personalnych [dalej: TAP] 7277, Akta personalne Kazimierza Porębskiego.

${ }^{13}$ CAW, TAP 7277, K. Porębski, Curriculum vitae. 
Ta właśnie wszechstronna wiedza i nieprzeciętne zdolności umożliwiły Porębskiemu błyskawiczną karierę i osiągnięcie najwyższych godności we flocie, w której afiszowanie się swoją polskością nie było mile widziane. Już jako cywil Porębski aktywnie włączył się do działalności organizacyjnej w środowisku piotrogrodzkiej Polonii. Wybrany na przewodniczącego Polskiej Rady Ekonomicznej, skupiającej wielu wybitnych specjalistów w dziedzinie gospodarki morskiej, wniósł istotny wkład w wypracowanie wstępnych koncepcji przyszłej polskiej polityki morskiej ${ }^{14}$.

Koncepcje te, po przyjeździe do Warszawy, propagował początkowo jako prezes Stowarzyszenia Pracowników na Polu Rozwoju Żeglugi „Bandera Polska”, a od marca 1919 r. już jako członek Rady Wojennej Ministerstwa Spraw Wojskowych ${ }^{15}$.

Na posiedzeniach Rady kontradmirał Kazimierz Porębski, używając argumentów historycznych, politycznych i gospodarczych, bardzo mocno akcentował konieczność powrotu Polski nad Bałtyk. Sprawiedliwy dostęp Polski do morza w jego opinii oznaczał przywrócenie jej granic z czasów przedrozbiorowych ${ }^{16}$. Uwzględniając jednakże różne warianty rozwiązania tej kwestii, na konferencji pokojowej w Paryżu zaproponował utworzenie jednej silnej instytucji morskiej, która niezależnie od postanowień traktatowych potrafiłaby zadbać o polskie interesy na Bałtyku.

Projekt ten zaowocował przekształceniem, na mocy dekretu Naczelnika Państwa z 2 maja 1919 r., Sekcji Marynarki przy Ministerstwie Spraw Wojskowych w Departament dla Spraw Morskich (DSM). Szefowi Departamentu, którym został kontradmirał Porębski, podporządkowano całość spraw odnoszących się zarówno do marynarki wojennej, jak i marynarki handlowej ${ }^{17}$.

Wiosną 1919 r. wiedziano już, że Rzeczpospolita uzyska dostęp do morza, natomiast $w$ dalszym ciągu nie rozstrzygnięta była kwestia, jaki będzie ten dostęp i czy Gdańsk będzie należał do Polski. W tej sytuacji kontradmirał Porębski za jedno z priorytetowych zadań podległego mu Departamentu dla Spraw Morskich uznał przygotowanie marynarzy do przejęcia odpowiedzialności za bezpieczeństwo polskiego Wybrzeża. Było to zadanie nie tylko niezwykle ważne, ale także niezwykle trudne z uwagi na problemy gospodarcze odradzającego się państwa. Ochotnikom

${ }^{14}$ C. CIesIelski, Twórcy Polskiej Marynarki Wojennej, s. 12; Z. Machaliński, Wiceadmirat Kazimierz Porębski (1872-1933) - kontradmirat rosyjskiej marynarki wojennej, szef Departamentu dla Spraw Morskich, szef Kierownictwa Marynarki Wojennej, „Nautologia”, 1987, nr 3, s. 5; K. BorCHARDT, Znaczy równik, s. 23; Wspomnienia pośmiertne o śp. Porębskim Kazimierzu, „Przegląd Morski”, 1933, nr 49, s. 11.

15 R. Czarnecka, Organizacja Ministerstwa Spraw Wojskowych (Mswojsk.) w latach 1918-1921, „Biuletyn Wojskowej Służby Archiwalnej”, 2009, nr 27, s. 87.

${ }^{16}$ Archiwum Akt Nowych, KNP, 1441, K. Porębski, Znaczenie ekonomiczne Gdańska, Warszawa 26.01.1919 r.; por. K. PorĘBSKI, Sprawy morskie Polski, Gdynia 1996, s. 74-79.

${ }^{17}$ S.M. PiaskowsKi, Kroniki, s. 26. 
trafiającym do Batalionu Morskiego (trzy kompanie: dwie strzeleckie i jedna ciężkich karabinów maszynowych), stacjonującego w Modlinie, przyszło pełnić służbę w prawdziwie spartańskich warunkach. Zakwaterowani, w zdewastowanych poniemieckich koszarach, zimnych i wilgotnych, noce spędzali na żelaznych łóżkach ze słomianymi materacami pod jednym kocem. Ich jadłospis był nie tylko skromny, ale także monotonny. Na śniadania i kolacje otrzymywali kawę zbożową, czarny chleb oraz kostkę sztucznego miodu lub buraczanej marmolady, a na obiad „cienką" kartoflankę z kawałkiem mięsa. Dla ochotników z cywila brakowało mundurów (ochotnicy z flot państw zaborczych donaszali swoje stare mundury), toteż przez kilka pierwszych tygodni nosili swoje cywilne ubrania. Jedyną oznaką ich przynależności do Batalionu Morskiego były poniemieckie okrągłe czapki polowe, bez daszków z czerwonym otokiem. Dopiero w marcu przed pierwszą marynarską przysięgą wojskową (16 marca 1919 r.) otrzymali właściwe dla tej formacji mundury.

Pierwszy w historii II Rzeczypospolitej mundur marynarski składał się z kurtki i spodni w kolorze szarym (tzw. szczupaczym) z niebieskimi wypustkami (u oficerów) oraz czarnych kamaszy (oficerowie) i trzewików (marynarze). Na naramiennikach obwiedzionych niebieską i białą wypustką (u oficerów srebrnych, plecionych) żółte metalowe kotwice. Czapka oficerska szara z wypustką niebieską i białą, srebrną rozetką oficerską na otoku i srebrną podpinką oraz orzełkiem legionowym z żółtą metalową kotwicą na niebieskiej tarczy amazonek; czapka podoficerska i marynarska granatowa bez daszka z czarną długą wstążką na otoku i orzełkiem jak u oficerów. Płaszcz długi szary kroju oficerskiego lub żołnierskiego, z naramiennikami jak na kurtkach mundurowych. Ponadto buty z żółtej twardej skóry ${ }^{18}$.

Niestety, umundurowanie, z zachwytem odebrane szczególnie przez szeregowych marynarzy, było uszyte $\mathrm{z}$ lichego ciemnogranatowego materiału (jak wtedy mówiono: z „pokrzyw”). Kiedy zatem kpt. mar. Konstanty Jacynicz ${ }^{19}$, dowódca Batalionu Morskiego, zarządził defiladę, jak wspomina jeden z jej uczestników: „marsz paradny wypadł dziarsko, ale koniec był żałosny. Pod wpływem rzęsistego deszczu czapki marynarskie oklapły jak jarmułki, a ubrania puściły farbę niebieską, którą dopiero po wielu dniach udało się nam usunąć z ciała"20.

To skądinąd przykre zdarzenie nie zmieniło na ogół wręcz entuzjastycznego nastawienia marynarzy do służby wojskowej. Szczególnym tego wyrazem były słowa piosenki ułożonej przez poborowych z rejonu Mazowsza:

\footnotetext{
18 A. Kostrzewski, Pierwszy mundur PMW, „Morze”, 1979, nr 4, s. 4.

${ }^{19}$ Kpt. mar. Konstanty Jacynicz (ur. 22.12.1896 w Mitawie na Łotwie), absolwent Morskiego Korpusu w Petersburgu z 1910 r.; do Polskiej Marynarki Wojennej przyjęty został jesienią 1918 r. 1 lipca 1920 r. mianowany został dowódcą Pułku Morskiego.

${ }^{20}$ Cz. WNorowski, Początki mojej stużby w Marynarce Wojennej, „Nasze Sygnały” [Londyn], 1980, nr 144, s. 4.
} 


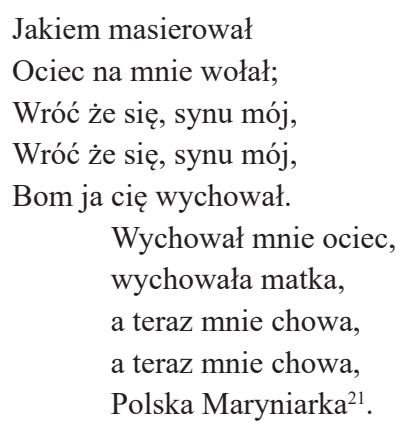

Pod koniec maja, nie do końca jeszcze sformułowany, Batalion Morski włączony został w skład tzw. Frontu Przeciwniemieckiego. Do utworzenia takiego frontu doszło pod wpływem zagrożenia wojennego ze strony Niemiec, sprzeciwiających się planom przekazania Pomorza odrodzonej Polsce ${ }^{22}$.

Pierwsze dwie kompanie marynarzy na granicę demarkacyjną w rejonie Aleksandrowa Kujawskiego trafiły już 9 czerwca. Trzecia dotarła tam dopiero 29 lipca, czyli po podpisaniu układu wersalskiego, gdy napięcie w relacjach niemiecko-polskich znacznie już osłabło. Znalazło to swój wyraz w rozwiązaniu Frontu Przeciwniemieckiego. Większość jego wojsk skierowano na front wojny rosyjsko-polskiej, a z pozostałych przewidzianych do rewindykacji Pomorza utworzono Front Pomorski, pod dowództwem gen. por. Józefa Hallera. W skład Frontu Pomorskiego włączony został także Batalion Morski, któremu powierzono ochronę granicy demarkacyjnej na odcinku od Aleksandrowa Kujawskiego do linii Wisły.

Czas oczekiwania na rozkaz do podjęcia marszu ku morzu umożliwił Departamentowi dla Spraw Morskich dalszą rozbudowę kadrową Batalionu Morskiego. Batalion nadal rozbudowywany był w dużej mierze przez ochotników. Jednym z takich ochotników, który do Aleksandrowa Kujawskiego dotarł w pierwszych dniach grudnia, był ksiądz Władysław Miegońn ${ }^{23}$.

Ten niezwykły ksiądz, obecnie pierwszy marynarz wyniesiony przez Kościół na ołtarze, bardzo szybko stał się duchowym przywódcą marynarzy. Jego działalność duszpasterska, a w tym wspólne dla całego stanu osobowego niedzielne nabożeństwa odegrały ważną rolę w integracji oficerów, podoficerów i marynarzy batalionu. W swoich kazaniach uwzględniając niski poziom znajomości polskich

${ }^{21}$ Tamże, s. 5.

${ }^{22}$ Szerzej P. Łossowski, Między wojna a pokojem, Warszawa 1976, s. 161-223.

${ }^{23}$ Z. JAWORSKI, D. NAWROT, Błogosławiony ks. Kmdr ppor. Władysław Miegoń pierwszy kapelan Marynarki wojennej II RP, Warszawa 1999, s. 22. 
tradycji przez marynarzy wychowywanych w szkołach państw zaborczych, odwoływał się do przeszłości Rzeczypospolitej i wielkich sukcesów oręża polskiego. W prostych zrozumiałych dla każdego słowach łącząc elementy wiary i patriotyzmu, podkreślał, że odrodzenie Polski dokonało się dzięki sprawiedliwości Bożej, a zatem służba marynarska jest nie tylko obywatelskim obowiązkiem, ale także realizacją woli Boga ${ }^{24}$. Wszystko to robił z myślą o jak najlepszym przygotowaniu marynarzy do przejęcia odpowiedzialności za bezpieczeństwo na obszarze Pomorza, przyznanego Polsce na mocy traktatu wersalskiego.

O ostatecznym terminie podjęcia tej misji przez marynarzy zadecydowała umowa polsko-niemiecka z 25 listopada $1919 \mathrm{r}^{25}$ Zgodnie z tą umową Batalion Morski ( 85 oficerów, 572 podoficerów i marynarzy) w dniu 17 stycznia 1920 r. o godzinie 06.00 rano przekroczył polsko-niemiecką granicę demarkacyjną. Maszerując po zaśnieżonych drogach, 18 stycznia w godzinach przedpołudniowych marynarze wkroczyli do Torunia, gdzie pomimo dotkliwego mrozu czekało ich entuzjastyczne powitanie zorganizowane przez miejscową Polonię ${ }^{26}$.

Do końca stycznia marynarze przejęli kontrolę nad kolejnymi portami rzecznymi w Bydgoszczy, Chełmie, Grudziądzu i Tczewie. Do Pucka, który był ich głównym celem, dotarli 10 lutego 1920 r. W tym uroczystym dniu szef Departamentu dla Spraw Morskich kontradmirał Kazimierz Porębski towarzysząc generałowi Józefowi Hallerowi dokonał aktu symbolicznych zaślubin Polski z morzem. Na jego rozkaz wciągnięto na maszt polską banderę wojenną, jako symbol objęcia wachty nad Bałtykiem ${ }^{27}$.

$\mathrm{Z}$ tym też dniem, na mocy traktatu wersalskiego, Polska weszła w posiadanie wybrzeża morskiego, które niestety licząc od ujścia Piaśnicy do folwarku Kolibki koło Orłowa obejmowało zaledwie 76 km (razem z Półwyspem Helskim - 140 km). Ponadto ten polski dostep do morza stanowił teren całkowicie gospodarczo zaniedbany, nieposiadający nawet zaczątków przemysłu okrętowego. W tych warunkach, mimo iż Puck pozbawiony był wszelkich urządzeń niezbędnych flocie morskiej, utworzono tam Dowództwo Wybrzeża Morskiego, Komendę Portu Wojennego i Dowództwo Artylerii Nadbrzeżnej oraz przystąpiono do tworzenia lotnictwa morskiego ${ }^{28}$.

Niestety, już pół roku później rozbudowę bazy morskiej zakłóciły dramatyczne wydarzenia na froncie wojny polsko-rosyjskiej. W obliczu bezpośredniego zagrożenia suwerenności Polski szef Departamentu dla Spraw Morskich wystąpił

\footnotetext{
${ }^{24}$ Cz. Wnorowski, Początki mojej stużby, s. 20.

${ }^{25}$ J. MaKowski, Zbiór umów i układów zawartych między rządem polskim i niemieckim w Berlinie i w Paryżu w roku 1919 i w styczniu 1920, Poznań 1920, s. 141.

${ }^{26}$ W Toruniu, „Dziennik Poznański”, nr 33 z 11 II 1920, s. 1.

${ }^{27}$ S.M. PiaskowsKi, Kroniki, s. 29.

${ }^{28}$ Tamże, s. 29-36.
} 
do Ministerstwa Spraw Wojskowych z wnioskiem o utworzenie z marynarzy oddziału do walk na froncie w roli piechoty. Przychylając się do tego wniosku, 6 lipca 1920 r. Minister Spraw Wojskowych wydał rozkaz powołujący Pułk Morski. Pułk, którego dowódcą został mianowany kpt. mar. Konstanty Jacynicz, składał się $\mathrm{z}$ trzech batalionów ${ }^{29}$. Niestety, nie udało się skierować jednocześnie na front wszystkich batalionów. $Z$ uwagi na zagrożenie Warszawy atakiem wojsk bolszewickich poszczególne bataliony natychmiast po sformowaniu wysyłano kolejno na front.

Jako pierwszy w dniu 19 lipca 1920 r. wyruszył pod Grodno II batalion, pod dowództwem kpt. mar. Adama Mohuczego. W jego skład wchodziło 7 oficerów, 5 podchorążych, 50 podoficerów i 377 marynarzy. Podstawowe uzbrojenie marynarzy stanowiły ręczne karabiny typu „Mosin”30.

Batalion na froncie podporządkowany został dowódcy 18 Brygady Piechoty, dowodzonej przez pułkownika Aleksandra Łuczyńskiego. W tym ugrupowaniu marynarze przeszli swój chrzest bojowy, 24 lipca. Tego dnia współdziałając z żołnierzami 34 pułku piechoty odparli pod Czechowszczyzną kilka ataków rosyjskich i przeszli do kontrataku. Goniąc uciekających dotarli do przedmieść Grodna. Jeszcze tego samego dnia, zgodnie z rozkazem dowódcy 18 Brygady Piechoty, podjęli odwrót w kierunku Tykocina. Tam w związku z reorganizacją Frontu Południowo-Wschodniego marynarze zostali włączeni w skład Grupy Operacyjnej, dowodzonej przez generała Lucjana Żeligowskiego.

27 lipca 2 batalion Pułku Morskiego otrzymał zadanie obrony zagrożonych atakiem bolszewickim mostów na rzece Narew w rejonie Siekierki - Złotoria - Żółtki. $\mathrm{Na}$ linii frontu marynarze znaleźli się jeszcze tego samego dnia późnym wieczorem, w momencie gdy walczące na tym odcinku pododdziały 2 dywizji litewsko-białoruskiej zmuszone zostały do odwrotu. O odbiciu z rąk rosyjskich, niezwykle ważnych pod względem strategicznym, mostów zadecydował brawurowy kontratak w wykonaniu dwóch plutonów marynarskich. Wkrótce jednak po obsadzeniu przez marynarzy powierzonego ich pieczy odcinka frontu doszło do kolejnych prób sforsowania mostów przez wojska rosyjskie. Pomimo przewagi liczbowej nieprzyjaciela marynarze dysponujący tylko jednym karabinem maszynowym odparli wszystkie idące na nich ataki. Ostatni atak, gdy skończyła się im amunicja, odparli walcząc na bagnety. W boju tym zginęło około 120 bolszewickich żołnierzy, a 35 zostało wziętych przez marynarzy do niewoli ${ }^{31}$.

\footnotetext{
${ }^{29}$ Tamże, s. 34.

${ }^{30}$ J. PRZYBYLSki, Marynarka Wojenna w walce o granice i niepodległość Polski (1918-1920), Gdynia 1997, s. 85.

${ }^{31}$ Tamże, s. 95.
} 
W rozkazie operacyjnym wydanym tego dnia (29 lipca) przez generała Lucjana Żeligowskiego znalazły się znamienne słowa: „Za utrzymanie przyczółka mostowego Złotoria - Żóltki i brawurowe pięciokrotne odparcie ataków nieprzyjaciela wyrażam swe uznanie kapitanowi Mohuczemu, oficerom, podoficerom i marynarzom i liczę na to, że 2 batalion morski nie zawiedzie mnie nigdy i nadal będzie bohatersko odpierał nawałę bolszewicką" ${ }^{\prime 32}$.

W podobnie ciężkich walkach opóźniających marsz armii rosyjskiej na Warszawę, marynarze uczestniczyli w składzie Grupy Operacyjnej generała Żeligowskiego przez prawie dwa tygodnie. Maszerowano głównie nocą, a w dzień, w pośpiesznie budowanych okopach, stawiano opór atakującemu wrogowi. W toku tych walk zginęło 14 marynarzy, a 26 odniosło ciężkie rany. 9 sierpnia w celu uzupełnienia tych strat II batalion skierowano do Torunia ${ }^{33}$.

I batalion, przy którym znajdował się dowódca pułku, kpt. mar. Konstanty Jacynicz i mianowany kapelanem pułku ksiądz kpt. mar. Władysław Miegoń, wyruszył na front w dniu 31 lipca 1919 r. Batalion ten był najsilniejszym (najliczniejszym) $\mathrm{z}$ batalionów Pułku Morskiego. W dniu wyjazdu z Torunia wraz z dowództwem pułku liczył łącznie 756 ludzi, w tym: 16 oficerów, 6 podchorążych, 54 podoficerów i 680 marynarzy $^{34}$. Podstawowe uzbrojenie batalionu stanowiły ręczne karabiny produkcji rosyjskiej oraz ciężkie karabiny maszynowe typu „Maxim”35.

Batalion wszedł w skład grupy operacyjnej, której zadaniem było powstrzymanie rozwijanego w kierunku na Łomżę i Ostrołękę ataku 4 armii wojsk bolszewickich. Do Ostrołęki batalion przybył 3 sierpnia około godziny 7 rano, to jest w chwili spodziewanego ataku na to miasto. W związku z alarmującą wiadomością, że „,bolszewicy są tuż', marynarze po krótkiej zbiórce na peronie, w czasie której odbyli spowiedź powszechną i przyjęli z rąk księdza Miegonia absolucję in articulo moris (na wypadek śmierci), natychmiast skierowani zostali na wyznaczony im odcinek frontu, na lewym brzegu Narwii. Nim upłynęło 15 minut od opuszczenia w trybie alarmowym pociągu, salwy marynarskich karabinów rozdarły powietrze. Zażarty atak na zajmowane przez nich pośpiesznie pozycje obronne przypuściły rosyjskie oddziały 15 Dywizji Kawalerii. Bitwa ta, będąca dla marynarzy chrztem bojowym, zakończyła się ich pełnym sukcesem. Po ponad dwugodzinnej walce atak wojsk sowieckich został odparty. Nie było jednak czasu na radość i fetowanie zwycięstwa. Kolejny rozkaz dowódcy grupy operacyjnej nakazywał batalionowi odbicie z rąk nieprzyjaciela

\footnotetext{
32 Z. MACHALIŃSKI, Admiratowie polscy 1919-1950, Gdańsk 1993, s. 266-267; J. PrZYBYLSKi, Marynarka Wojenna w walce, s. 95.

${ }^{33}$ R. Dziewaltowski-Gintowt, K. Taube, Zarys historii wojennej pułku morskiego, Warszawa 1933, s. 27.

${ }^{34}$ Por. M. Kulakowski, Marynarka Wojenna Polski Odrodzonej, Toronto 1988, s. 66-67.

35 J. PRZYBYLSKi, Marynarka Wojenna, s. 89.
} 
utraconych wcześniej miejscowości Susk i Nowa Wieś. W tym celu należało jednak wcześniej przeprowadzić rozpoznanie terenu przyszłej walki i zdobyć niezbędne informacje o rozmieszczeniu sił przeciwnika. Osiągnąć to można było jedynie poprzez skierowanie pododdziału rozpoznania na teren kontrolowany przez wroga. Ze względu na wagę tego zadania oraz związane z nim niebezpieczeństwo dowództwo pułku zdecydowało posłużyć się w tym celu ochotnikami. Niestety, na wezwanie odpowiedzialnego za realizację tego zadania por. mar. Michała Wilkickiego nie było większego odzewu. Zgłosił się tylko jeden podoficer i jeden marynarz. Niebezpieczne to zadanie wśród nieobytych jeszcze z frontem i walką na lądzie marynarzy wzbudzało po prostu zwykły ludzki strach. W tej kłopotliwej sytuacji z pomocą porucznikowi Wilkickiemu pośpieszył ksiądz kapelan, który widząc reakcje marynarzy zdecydował się własnym przykładem dodać im odwagi. Deklaracja księdza wyrażona słowami: „Ja idę!” sprawiła, że do patrolu zgłosiło się jeszcze ośmiu ochotników ${ }^{36}$.

Mimo iż dla kapelana wojaczka, a szczególnie prowadzenie rozpoznania w terenie, także stanowiło całkowite novum, to właśnie on w roli dowódcy z karabinem w ręku poprowadził patrol w kierunku opanowanego przez bolszewików folwarku Susk. Przeprowadzone przez kapelana i jego zwiadowców rozpoznanie umożliwiło zdekonspirowanie bolszewickich stanowisk ogniowych. Brawurowy atak I batalionu Pułku Morskiego i odzyskanie miejscowości Susk znalazło odzwierciedlenie w meldunku dowódcy grupy operacyjnej, który w tym dniu odnotował: „Kilkakrotne silne ataki na Ostrołękę z północnego wschodu, odparto ze stratami obu stron. Rozpoczęte obejście miasta od południa na razie zlikwidowano za pomocą Baonu Morskiego, który bije się doskonale?"37.

Niestety, kolejny dzień walk frontowych był mniej fortunny dla marynarzy. Pod osłoną zmasowanego ognia artyleryjskiego na polską linię obrony runął potężny atak sowieckiej piechoty. Mimo bohaterskiej obrony marynarze oraz wspierający ich 2 pułk ułanów zostali zmuszeni do chwilowego opuszczenia zajmowanej pozycji na linii Susk-Nowa Wieś.

To pierwsze na froncie niepowodzenie nie było jednak w stanie załamać ducha bojowego marynarzy i wkrótce kontratak 1 batalionu poprowadzony osobiście przez dowódcę pułku, kpt. mar. Konstantego Jacynicza, nie tylko przywrócił poprzednią linię obrony, ale odbił także z rąk sowieckich położoną o 3 kilometry dalej wieś Zabiele. Zanim jednak marynarze zdążyli umocnić się na nowej rubieży, runęło na nich potężne

\footnotetext{
${ }^{36}$ Pamiętnikx. Miegoń Władystawa z 29.XI. 1929 r. Archiwum Seminarium Duchownego w Sandomierzu na prawach rękopisu, s. 2-3.

${ }^{37}$ Materiaty do historii wojny 1918-1920 r. Bitwa Warszawska, t. I: Bitwa nad Bugiem, cz. 2. Dokumenty operacyjne, nr 452. Grupa gen. Wroczyńskiego. Akta operacyjne. Teka Nr 1152. Cytat za: J. PrZYBYLSKI, Marynarka Wojenna, s. 52.
} 
uderzenie trzech pułków kozackiej kawalerii. Rozbicie szwadronu ułanów, osłaniającego lewe skrzydło batalionu sprawiło, że marynarze zostali wzięci w krzyżowy ogień przeciwnika. Doszło do rozerwania linii polskiej obrony. Mimo iż w krwawej i nierównej walce rozdrobnione marynarskie pododdziały ponosiły ciężkie straty, batalion dalej walczył z przeważającymi siłami wroga ${ }^{38}$.

$\mathrm{Z}$ dramatycznej sytuacji, zagrażającej całkowitym zniszczeniem batalionu, wyratował marynarzy celny ogień skierowanej im na pomoc artylerii, która powstrzymała dalszy atak bolszewicki. Straty były jednak poważne. Do niewoli dostał się dowódca pułku, kapitan marynarki Konstanty Jacynicz, ranni zostali porucznicy Tomasz Duracz i Roman Pieńkowski. Zginęło 25 marynarzy, wielu było rannych. Mimo dotkliwych strat batalion w tym dniu odparł jeszcze kilka sowieckich ataków.

Dowódca Grupy Operacyjnej, generał Bolesław Roja, w swoim rozkazie dziennym napisał wówczas: „Dziś nieprzyjaciel mimo kilkakrotnych ataków wszędzie odparty, przyczep szczególnym męstwem wyróżnił się Baon Morski”. W dwa dni później Naczelne Dowództwo Wojska Polskiego w komunikacie prasowym informowało: „Nieprzyjaciel w dalszym ciągu atakuje Ostrołękę [...]. Podkreślić należy pełną brawury działalność marynarzy na tym odcinku"39.

W nocy z 6 na 7 sierpnia, w związku z reorganizacją i przegrupowaniem Frontu Północno-Wschodniego, batalion otrzymał rozkaz wycofania się przez Różan i Tłuszcz w rejon Makowa Mazowieckiego. Kolejnymi etapami na szlaku bojowym 1 Batalionu Morskiego były miejscowości położone na trasie Nasielsk-Płońsk. Tam to w dniu 17 sierpnia na obsadzoną przez marynarzy linię obronną Ilino-Ćwiklin nieprzyjaciel poprowadził kolejne bardzo silne uderzenie. Do szczególnie zażartych walk doszło wówczas pod Ćwiklinem, gdzie wojska sowieckie dysponujące ogromną przewagą odrzuciły broniący się tam razem z marynarzami 4 pomorski pułk piechoty. Na stanowiskach pozostał wówczas jedynie pluton dowodzony przez por. mar. Aleksandra Hulewicza. Niemal w ostatniej chwili marynarzom, śmiertelnie zagrożonym sowieckim atakiem, skutecznej pomocy udzielił 201 pułk szwoleżerów, który brawurową szarżą odrzucił atakującego nieprzyjaciela.

Nazajutrz (18 sierpnia) 1 Batalion Morski wszedł w skład nowo utworzonej grupy operacyjnej pułkownika Franciszka Zielińskiego. W nowym układzie organizacyjnym batalion skierowany został w rejon Baboszewo-Dzierżążnia, gdzie walczył następnie w obronie Cywin ${ }^{40}$.

${ }^{38}$ CAW, Akta Departamentu dla Spraw Morskich i Kierownictwa Marynarki Wojennej, sygn. 34/2579, Kazimierz Porębski VM.

${ }^{39}$ Cytat za: R. Dziewaltowski-Gintowt, K. Taube, Zarys historii wojennej pułku, s. 33.

${ }^{40}$ CAW, Akta Departamentu dla Spraw Morskich i Kierownictwa Marynarki Wojennej, sygn. KW79/2240, Wniosek na odznaczenie Krzyżem Walecznych ks. Kapelana W. Miegonia. 
Marynarze walczący w całkowicie obcych im warunkach, mimo dotkliwych braków w umundurowaniu i uzbrojeniu, zdobywając sobie słowa najwyższego uznania, znosili trudy walki odwrotowej i wzięli również udział w walkach nad Wisłą, w których wojska rosyjskie poniosły druzgocącą klęskę.

W dniu 25 sierpnia na wniosek szefa Departamentu dla Spraw Morskich batalion został wycofany z frontu i skierowany z powrotem do Torunia. Po zakończeniu walk I batalion liczył: 10 oficerów i 310 marynarzy, tj. 42\% stanu osobowego, z którym wyruszył na front.

W tym czasie, gdy I i II batalion był już na froncie, kontynuowane były prace nad formowaniem III batalionu Pułku Morskiego. Był to czas, gdy wojska bolszewickie docierały już na przedpola Torunia. Pomimo zatem niezakończonego procesu szkolenia III batalion (10 oficerów i podchorążych oraz 495 podoficerów i marynarzy) pod dowództwem kpt. mar. Włodzimierza Steyera obsadził 5, 6, 7, 8 i 9 fort Obozu Warownego Torun. Po bitwie warszawskiej, gdy wojska polskie przeszły do kontrofensywy, III batalion został włączony do grupy operacyjnej płk. Witolda Aleksandrowicza ${ }^{41}$. Działając w tej grupie marynarze 18 sierpnia odbili z rąk czerwonoarmistów Golub-Dobrzyń, a 22 sierpnia Jabłonowo.

W annały historii wojny polsko-bolszewickiej, obok marynarzy walczących na lądzie, w sposób nie mniej chwalebny wpisali się marynarze walczący na rzekach. Początek tym zmaganiom dały załogi trzech motorówek: Lech, Lisowczyk i Lizdejko, które pod dowództwem por. mar. Jana Giedroycia podjęły działania w kwietniu 1919 r. na wodach Prypeci. Zespół ten pełnił rolę patrolu rozpoznawczego w Grupie Poleskiej, dowodzonej przez generała Antoniego Listowskiego ${ }^{42}$. Wysoka ocena użyteczności tego zespołu zaowocowała rozkazem Ministra Spraw Wojskowych o powołaniu z dniem 1 maja 1919 r. Flotylli Pińskiej. W tym też miesiącu nowo utworzoną flotyllę wzmocniło kilkunastu marynarzy skierowanych przez szefa DSM z Flotylli Wiślanej. Tak wzmocniona Flotylla Pińska współdziałając z 34 pułkiem piechoty Grupy Podlaskiej, odbiła z rąk rosyjskich w dniu 3 lipca 1919 r. Horodyszcz.

W wydanym tego dnia rozkazie operacyjnym dowódca Grupy Poleskiej napisak: „wyrażam szczególną wdzięczność i słowa pochwały Flotylli Pińskiej pod dowództwem por. mar. Księcia Giedrojcia za inicjatywę i męstwo podczas zdobycia Horodyszcza" ${ }^{\text {"43 }}$.

W sierpniu do Pińska jako wzmocnienie Flotylli dotarło z Modlina kolejnych 28 marynarzy oraz dwie łodzie motorowe i statek „Bug”44. Tak wzmocniona flotylla

\footnotetext{
${ }^{41}$ R. Dziewialtowski-Gintowt, K. Taube, Zarys historii wojennej pulku, s. 44.

${ }^{42}$ Polskie Sity Zbrojne w drugiej wojnie światowej, t. I, cz. 5. Marynarka wojenna i obrona polskiego Wybrzeża, Londyn 1962, s. 5.

${ }^{43}$ K. Taube, O. Żukowski, Zarys historii wojennej flotyll rzecznych, Warszawa 1931, s. 9.

44 J.W. Dyskant, Flotylla Rzeczna Marynarki Wojennej 1919-1939, Warszawa 1994, s. 81.
} 
do późnej jesieni patrolowała Prypeć docierając aż do Petrykowa. W toku tych patroli kilkakrotnie doszło do spotkań z jednostkami rosyjskiej Flotylli Dnieprzańskiej. Historię jednego z takich spotkań opisał w swoim meldunku operacyjnym dowódca 9 DP pułkownik Władysław Sikorski słowami: „Flotylla bolszewicka w składzie 3-ch doskonale opancerzonych i uzbrojonych statków natknęła się na własne łodzie motorowe pełniące straż na Prypeci. Własne łodzie motorowe, jakkolwiek nie opancerzone, wykonały nagły napad ogniowy na flotyllę bolszewicką. [...] Po zaciętej walce flotylla własna statki bolszewickie zawróciły w dół rzeki”45.

Jeszcze większy sukces przyniosło współdziałanie marynarzy Flotylli Pińskiej z żołnierzami 9 DP wiosną 1920 r. Wspólny wypad na Mozyrz i Kalenkowicze w dniach od 4 do 7 marca zaowocował przejęciem zimujących tam jednostek Floty1li Dnieprzańskiej: 22 parowców, 61 barek rzecznych i 19 tratew $^{46}$. Celem ukompletowania ich załóg kontradmirał Kazimierz Porębski skierował z Modlina do Pińska ponad 200 marynarzy.

Tak rozbudowywana Flotylla w dniu rozpoczęcia przez Wojsko Polskie wielkiej ofensywy na Ukrainie liczyła 333 oficerów, podoficerów i marynarzy. Ten stan osobowy pozwalał na obsadzenie 36 jednostek podzielonych na dwa oddziały: Bojowy i Transportowy. Oddział Bojowy składał się z jednej kanonierki („Pancerny 1”), sześciu kutrów uzbrojonych („MP1”, „MB1”, „MB2” i „MB3”) i dwóch kutrów zwiadowczych (,W1” i „W2”). Oddział Transportowy tworzyło 9 okrętów pomocniczych i 18 barek.

Pierwszą regularną bitwę Flotylla Pińska stoczyła pod Czarnobylem 27 kwietnia 1920 roku. W bitwie tej Oddział Bojowy (kanonierka „Pancerny1” i 6 kutrów motorowych) pod dowództwem kpt. mar. Aleksandra Olszewskiego zmierzył się z sześcioma jednostkami Flotylli Dnieprzańskiej. Dwugodzinna bitwa zakończyła się pełnym sukcesem polskich marynarzy. Celnym ogniem okrętowej artylerii posłali na dno kanonierkę „Gubitelnyj”. Pozostałe okręty rosyjskie w popłochu opuściły pole bitwy wycofując się na Dniepr ${ }^{47}$.

W ślad za rosyjskimi okrętami na Dniepr wpłynęły jednostki Flotylli Pińskiej. Współdziałając z oddziałami piechoty, 16 maja 1920 r. dotarły do Kijowa. Wyrazem znaczącej roli marynarzy w tej operacji był wniosek dowódcy 3 Armii WP, generała Edwarda Rydza-Śmigłego do Ministra Spraw Wojskowych o utworzenie kijowskiego oddziału Flotylli Pińskiej. Nie doszło do tego z powodu rosyjskiej

\footnotetext{
${ }^{45}$ K. Taube, O. Żukowski, Zarys historii wojennej, s. 13.

${ }^{46}$ W. Wicherski, Polskie Flotylle Rzeczne 1918-1939. Zarys historyczny, „Nasze Sygnały” [Londyn], 1989, nr 163, s. 9

${ }^{47}$ S.M. PiaskowsKi, Kroniki, s. 30.
} 
kontrofensywy, która zmusiła 3 Armię, a w tym jednostki Flotylli Pińskiej do szybkiego odwrotu. Niestety, z powodu bardzo niskiego stanu wody na Prypeci do Pińska udało się przeprawić tylko mniejsze jednostki. Tam 24 lipca w obliczu bezpośredniego zagrożenia atakiem rosyjskim, na rozkaz Dowództwa Grupy Poleskiej, zniszczono i zatopiono wszystkie znajdujące się jeszcze w użytkowaniu jednostki Flotylli Pińskiej. Ich załogi wzmocniły Flotyllę Wiślaną, która w obliczu bolszewickiego ataku na Warszawę otrzymała zadanie obrony przepraw na linii od Karczewa do Torunia. Do realizacji tego zadania dowódca Flotylli Wiślanej, kpt. mar. Bohdan Jarociński dysponował zaledwie 9 statkami i 16 motorówkami. Ich załogi stanowiło 26 oficerów oraz 217 podoficerów i marynarzy ${ }^{48}$. Pomimo tak skromnych rozmiarów Flotylla Wiślana odegrała znaczącą rolę w obronie przepraw w rejonie Nieszawy, Włocławka i Płocka.

O niebagatelnej roli Flotylli Wiślanej w tych walkach świadczą słowa z rozkazu generała Józef Hallera wydanego z okazji zakończenia bitwy warszawskiej: „W gwałtownym ogniu nieprzyjacielskim ostrzeliwała celnie pozycje wroga, współdziałając znakomicie z akcją bojową piechoty. Podnoszę znakomita działalność statków: Batory, Moniuszko, Wawel pod Płockiem - zwłaszcza bohaterska załoga statku «Batory» zasługuje na wyróżnienie" ${ }^{49}$.

Ogółem w wojnie polsko-rosyjskiej uczestniczyło 142 oficerów oraz 2389 podoficerów i marynarzy. Podczas walk zginęło ponad 200 marynarzy, a rannych zostało ok. 800 osób. Łącznie straty bojowe Polskiej Marynarki Wojennej wyniosły ponad $45 \%$ ogółu walczących. O postawie i roli marynarzy w tej wojnie oraz ich wkładzie w ostateczne zwycięstwo nad bolszewikami świadczy m.in. nadanie im 37 orderów Virtuti Militari, co oznacza, iż to wyjątkowe odznaczenie otrzymał co 60. marynarz. W ten sposób marynarze uplasowali się w ścisłej czołówce oddziałów o porównywalnej wielkości, które szczycą się takimi osiągnięciami. Cena, jaką wówczas zapłaciła za to Polska Marynarka Wojenna, była ogromna. Do koszar i na okręty nie powróciło ponad $30 \%$ marynarzy.

BIBLIOGRAFIA

MATERIAEY ARCHIWALNE

Archiwum Akt Nowych - Warszawa

- Akta Komitetu Narodowego Polski

48 J.W. Dyskant, Wojenne Flotylle Wiślane 1918-1939, Warszawa 1997, s. 222-230.

49 J. PRZYBYLSKI, Marynarka Wojenna, s. 145. 
Centralne Archiwum Wojskowe - Warszawa

- Akta Departamentu dla Spraw Morskich i Kierownictwa Marynarki Wojennej

Archiwum Seminarium Duchownego w Sandomierzu

- Pamiętnik x. Miegoń Władysława z 29 listopada 1929 r.

ARTYKUŁY

Czarnecka R., Organizacja Ministerstwa Spraw Wojskowych (Mswojsk.) w latach 1918-1921, „Biuletyn Wojskowej Służby Archiwalnej”, 2005.

Czerwiśski J., Wiceadmirat Kazimierz Porębski, ,, Nasze Sygnały” [Londyn], 1988, nr 162.

Kostrzewski A., Pierwszy mundur PMW, „Morze”, 1979, nr 4.

MaChaLIŃski Z., Michał Borowski, „Nautologia” [Gdynia], 1986, nr 4.

MACHALIŃsKi Z., Wiceadmirat Kazimierz Porębski (1872-1933) - kontradmirat rosyjskiej marynarki wojennej, szef Departamentu dla Spraw Morskich, szef Kierownictwa Marynarki Wojennej, ,, Nautologia", 1987, $\mathrm{nr} 3$.

Nawrot D., Akcja w Kanale Porto Corsini i bitwa w Cieśninie Otranto, czyli rzecz o bojowych dokonaniach Bogumiła Nowotnego pod czerwono - biało - czerwona bandera, „Colloquim” Wydział Nauk Humanistycznych i Społecznych Akademii Marynarki Wojennej [Gdynia], 2011, nr 4.

Wicherski W., Polskie Flotylle Rzeczne 1918-1939. Zarys historyczny, „Nasze Sygnały” [Londyn], 1989, nr 163.

Wspomnienia pośmiertne o śp. Porębskim Kazimierzu, „, Przegląd Morski” [Gdynia], 1933, nr 49.

\section{OPRACOWANIA}

BARdach J., LeŚnOdorski B., PietrzaK M., Historia ustroju i prawa polskiego, Warszawa 2009.

Błogosławiony Ks. Kmdr ppor. Władysław Miegoń. Materiaty z sesji towarzyszacej obchodom 80 rocznicy Zaślubin Polski z Morzem, red. D. Duda [i in.], Puck 2000.

BorChARDT K., Znaczy równik na rumbie, Gdańsk 1992.

Ciesielski Cz., Twórcy Polskiej Marynarki Wojennej. Uznanie i represje (1918-1946;1945-1951), Gdańsk 1995.

Dyskant J.W., Flotylla Rzeczna Marynarki Wojennej 1919-1939, Warszawa 1994.

Dyskant J.W., Wojenne Flotylle Wiślane 1918-1939, Warszawa 1997.

Dziewaltowski-Gintowt R., Taube K., Zarys historii wojennej pułku morskiego, Warszawa 1933.

JAWORSKi Z., NAWrot D., Błogosławiony ks. Kmdr ppor. Władysław Miegoń pierwszy kapelan Marynarki wojennej II RP, Warszawa 1999.

Komarnicki W., Polskie prawo polityczne, Warszawa 2008.

KuŁakowski M., Marynarka Wojenna Polski Odrodzonej, Toronto 1988.

Łossowski P., Między wojna a pokojem, Warszawa 1976.

MaChaliński Z., Admirałowie polscy 1919-1950, Gdańsk 1993.

MAKowski J., Zbiór umów i uktadów zawartych między rządem polskim i niemieckim w Berlinie i w Paryżu w roku 1919 i w styczniu 1920, Poznań 1920.

Materiaty do historii wojny 1918-1920 r. Bitwa Warszawska, t. I: Bitwa nad Bugiem, Warszawa 1935. Nawrot D., Korpus oficerski Marynarki Wojennej II Rzeczypospolitej, Warszawa 2005. 
NAwrot D., Zakon dżentelmenów morskich II Rzeczypospolitej, Gdynia 2018.

Nowotny B., Wspomnienia, Gdańsk 2006.

Polski Stownik Biograficzny, t. XXVII, Warszawa 1983.

Piaskowski S.M., Kroniki Polskiej Marynarki Wojennej 1918-1947, t. I, Albany 1983.

Polskie Sity Zbrojne w drugiej wojnie światowej, t. I, cz. 2. Kampania wrześniowa 1939, cz. 5. Marynarka wojenna i obrona polskiego Wybrzeża, Londyn 1962.

PoręBSKI K., Sprawy morskie Polski, Gdynia 1996.

PrZYBYLski J., Marynarka Wojenna w walce o granice i niepodległość Polski, (1918-1920), Gdynia 1997.

Roszak S., KŁaczkow J., Poznać przeszłość. Wiek XX, Warszawa 2015.

TAuBE K., ŻuKowski O., Zarys historii wojennej flotylli rzecznych, Warszawa 1931.

\title{
MARINERS IN THE FIGHT FOR POLAND'S BORDERS \\ AND INDEPENDENCE IN 1918-1920
}

\begin{abstract}
The role of the Polish Navy in the fight for Poland's borders and independence in 1918 - 1920 is a subject that has not been sufficiently analyzed in scholarly literature. There have been numerous publications on the birth of the Second Republic, but only a small fraction deals with the role of the Polish Navy in these events.

In my opinion, even a cursory overview of the exploits of mariners justifies the claim that their role was significant during both peace and war. The role of the Polish Navy was particularly prominent during the regaining of Pomerania and in the Polish-Russian war. It is worth adding that the mariners fought not only on water (the Pińsk and the Vistula River Flotillas), but also on land as infantry. The formation of the Navy Group by the Minister of the Internal Affairs was an event unprecedented in the history of military and was ordered by the contemporary commander of the Polish Navy, Rear Admiral Kazimierz Porębski.

The article discusses the intriguing topics of the birth, development, and operation of the Polish Navy during the building of the Second Republic. The discussion is based on the most recent research.
\end{abstract}

Keywords: Polish Navy; regaining of Pomerania; the Navy Group; commodore Bogumił Nowotny; rear admiral Kazimierz Porębski. 